\title{
SEISMIC AMPLIFICATION DETERMINED FROM MICROTREMOR MONITORING AT ALLUVIAL AND ROCK SITES IN NEWCASTLE
}

\author{
M. R. Somerville', H. Kagami², K. F. McCue ${ }^{3}$
}

\begin{abstract}
In the magnitude 5.6 Newcastle, N.S.W. earthquake of 28 December 1989, the area with highest seismic intensity (MM VIII) was located some $10 \mathrm{~km}$ from the epicentre. In the absence of local instrumental data for the event, various explanations of the intensity distribution have been advanced. A causative relationship has been suggested, with support from wave propagation calculations, in the close spatial correlation between the area with highest seismic intensity and the area with alluvial and/or fill cover. An alternative interpretation correlates intensity primarily with structural vulnerability rather than site geology. New evidence for amplified response of alluvial sites has been obtained from a microtremor monitoring experiment using $1-\mathrm{Hz}$ seismometers.

Amplified response was observed at frequencies ranging from $1.5 \mathrm{~Hz}$ to $10 \mathrm{~Hz}$, at sites with alluvial depth ranging from $40 \mathrm{~m}$ to $5 \mathrm{~m}$. Most of these observations have a straightforward interpretation in terms of fundamental-mode (quarter-wavelength) resonance of the alluvium overlying a substratum of much greater rigidity. At some sites there is amplification but the quarter-wavelength resonance is not identifiable, due to a steep interface between the alluvium and the substratum, or perhaps the lack of a sharp rigidity contrast. The microtremor results, while useful for determining site resonance frequencies, are not expected to replicate the degree of amplification under strong earthquake excitation. The microtremor amplification factors are generally higher than the factor $3 \pm 1$ inferred from the seismic intensity distribution of the 28 December, 1989 earthquake.
\end{abstract}

\section{BACKGROUND}

\section{Geologic Setting}

Newcastle is situated in the Sydney Basin near its northern margin. Underlying the Permian Newcastle Coal Measures, some $1.2 \mathrm{~km}$ in thickness, are several kilometres of Carboniferous sediments. The northeastern marginal zone of the Sydney Basin, known as the Hunter Valley Dome Belt, is bounded by the Hunter-Mooki Thrust System to the northeast, and by sub-parallel northwest-striking basement faults to the southwest of Newcastle (Herbert and Melby, 1980). With movement on the Hunter-Mooki Thrust System, sedimentation was primarily terrestrial in the Newcastle area, rather than marine as in the Sydney area, $100 \mathrm{~km}$ to the south.

The sea-level rise following the Pleistocene deglaciation resulted in sedimentation of river and stream channels in the Newcastle area. Alluvial, colluvial, estuarine and aeolian sediments, with total thickness up to $40 \mathrm{~m}$, are found in the immediate vicinity of Newcastle (Coffey Partners, 1990), and in some areas there is a cover of fill, mainly non-engineered fill. These young sediments overly Permian rocks that vary in their extent of weathering and saprolite cover. The possible seismic effect of pronounced contrast in rigidity between the young sediments and substrata is the subject of this investigation.

\begin{abstract}
Mainshock and Aftershock Focal Parameters
Inferences concerning wave propagation effects associated with the damage caused on 28 December 1989 depend on the estimated geographic location, focal depth, and mechanism of the earthquake. Of the hypocentral parameters, only the focal depth of the mainshock, $11.0 \pm 3.0 \mathrm{~km}$, is well-constrained (McCue \& others, 1990), by core-phase observations at the Lownet array in Scotland. With the focal depth thus constrained, the computed epicentre is near Boolaroo, some $15 \mathrm{~km}$ west-southwest of central Newcastle, with error-ellipse semi-axes of $17 \mathrm{~km}$ east-west and $7 \mathrm{~km}$ north-south.
\end{abstract}

By itself, the mainshock hypocentral determination does not give meaningful spatial resolution of the epicentre in relation to the area with highest seismic intensity (Figure 1). However, a precise hypocentre determined for the lone aftershock on 29 December (Gibson \& others, 1990) is within a few kilometres of the computed mainshock focus, providing strong evidence that the mainshock epicentre was near

1 Australian Seismological Centre, Bureau of Mineral Resources, GPO Box 378, Canberra ACT 2601, Australia

2 Faculty of Earthquake Engineering, Hokkaido University, North 13 West 8, Sapporo 080, Japan

3 Australian Seismological Centre, Bureau of Mineral Resources, GPO Box 378, Canberra ACT 2601, Australia (Member) 


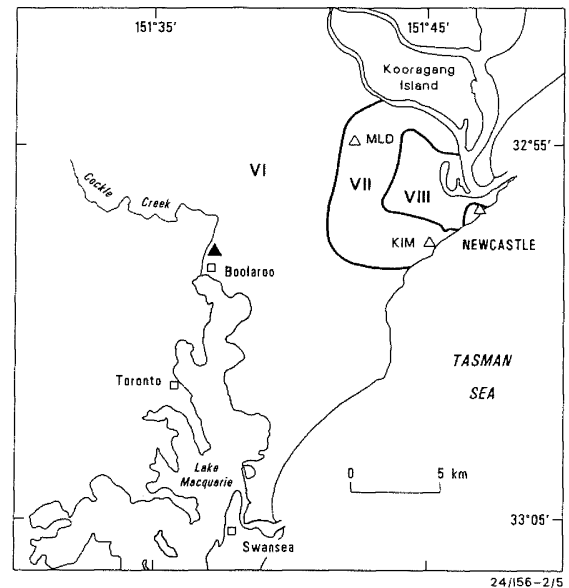

Figure 1 Modified Mercalli intensities in relation to the epicentre (triangle) near Boolaroo, of the 28 December 1989 earthquake. The open triangles are permanent seismograph sites which doubled as the reference rock sites for microtremor recording.

Boolaroo rather than Newcastle. The aftershock, recorded by a local array of ten seismographs installed after the mainshock, had a calculated focal depth of $13.7 \pm 2 \mathrm{~km}$. Given the similarity of mainshock and aftershock focal depths, the universal tendency of early aftershocks to cluster on mainshock ruptures or their edges, and the relatively small rupture dimension (a few $\mathrm{km}$ ) expected for an earthquake of this magnitude, the Boolaroo epicentre is strongly favoured over one near the centre of damage in Newcastle.
The focal mechanism determined for the mainshock (McCue $\&$ others, 1990) is thrust, with a northeasterly, near-horizontal axis of maximum compressive stress. The northwest-striking focal planes have dips of 75 to the northeast and 32 to the southwest. The plane dipping steeply to the northeast is preferred as the fault plane on the basis of geomorphic evidence (Gibson \& others, 1990). Rupture on the northeast-dipping plane would direct maximum shear-wave energy toward Newcastle, and so it is possible that the apparent seismic intensity anomaly is due in part to the radiation pattern.

\section{Interpretations of the Seismic Intensity Distribution}

The seismic intensity contours shown in Figure 1 are from the Newcastle Earthquake Study of the Institution of Engineers, Australia (IEAust, 1990). While another intensity map under preparation may differ from this (Rynn, 1991), the location of the area with highest seismic intensity (VIII on the Modified Mercalli scale) is well documented.

IEAust (1990) documented "a high degree of correlation between areas of significant damage and areas in which the foundation material consists of alluvial soil strata and/or fill" (Figure 2). The existence of a causative relationship was inferred from the results of approximate wave propagation calculations: a more comprehensive study has since been published by Poulos (1991). The amplification phenomenon stems from acoustic impedance contrast between low-rigidity alluvium and high-rigidity bedrock. For a uniform alluvial layer, the fundamental-mode resonance occurs at a frequency given by the shear wave velocity divided by four times the alluvial thickness. Poulos states (p.181): "It has been demonstrated that the extent of damage can be related to the computed spectral acceleration, and that, in turn, the spectral

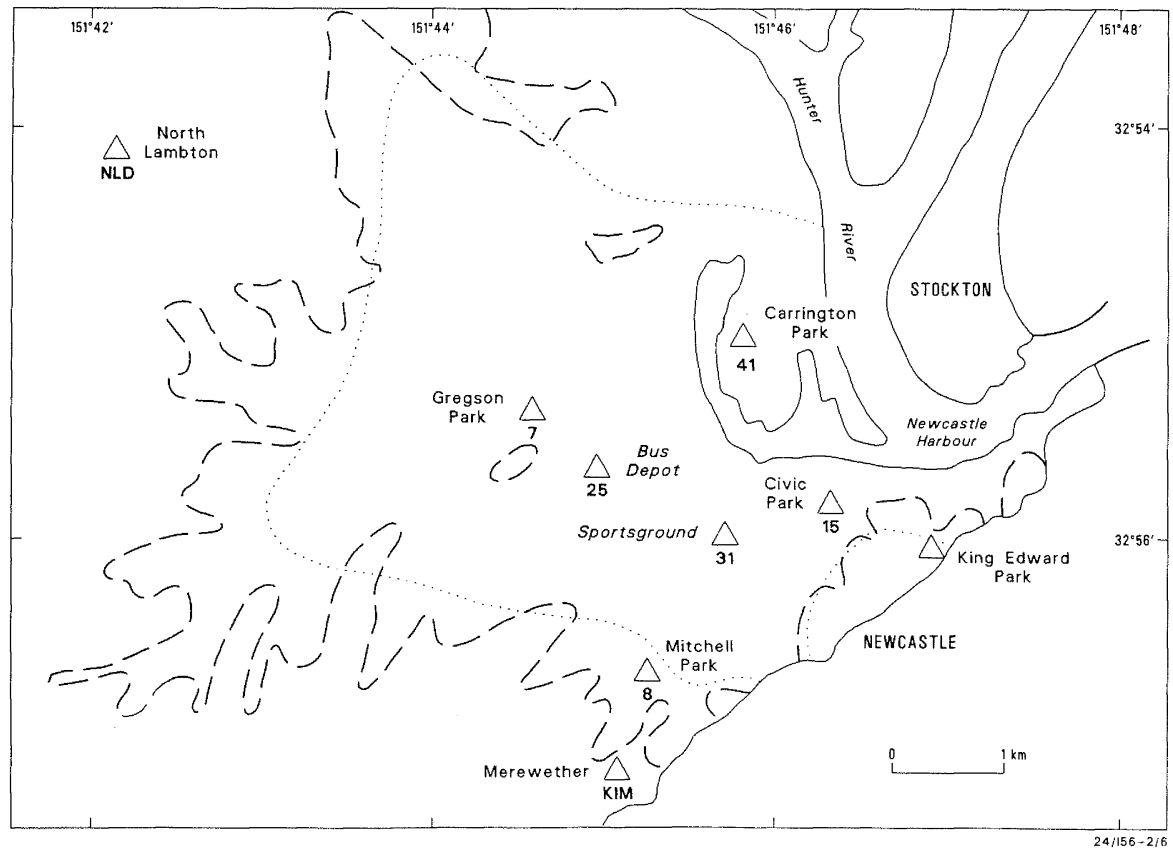

Figure 2 Correspondence between the area of alluvial and/or fill cover (dashed line) and the area of highest intensity. The open triangles are microtremor monitoring sites and the depth to bedrock $(m)$ is indicated. 
acceleration is related to the depth of soil and the number of storeys in the structure at the site."An alternate interpretation has been advanced by the UK-based Earthquake Engineering Field Investigation Team (Chandler et al., 1991), who argue that structural vulnerability factors were the primary determinant of the distribution of damage.The most convincing way of evaluating the role of alluvial site amplification would be to record earthquakes on an array of seismographs installed at numerous rock and alluvial sites in the Newcastle region. An extended aftershock sequence would have provided such an opportunity, but the aftershock activity comprised a single detected event.

\section{MICROTREMOR MONITORING EXPERIMENTS}

The energy source for the seismic response observations reported here is microtremor, ambient seismic "noise" arising from oceanic, atmospheric, and cultural disturbances. Microtremor signatures register effects of surficial geology, but not necessarily in a manner that is directly analogous to earthquake excitation. Microtremor observations nonetheless have been shown to provide significant site response information for shallow strata (e.g. Field \& others, 1990) as well as deep alluvium (e.g. Kagami \& others, 1986). Earthquake response and microtremor response of alluvial sites, and the relationship between the two, have been discussed at length by Field \& others (1990).

Microtremor recordings were made with six seismographs, comprising a Mark Products L4C3D 3-component $1-\mathrm{Hz}$ seismometer and a Kelunji digital seismograph manufactured by the Seismology Research Centre, Royal Melbourne Institute of Technology. The equipment is the same as that used by Gaull \& others (1991) in their microzonation study of Perth, and the inter-system response variation is no greater than $30 \%$ in the frequency band considered here. The first set of experiments consisted of instrument arrays triggered simultaneously in the early morning hours when cultural noise is minimum. The first array was oriented roughly east-west (Figure 2), with seismographs installed near the King Edward Park Obelisk, in Civic Park, at the No. 1 Sportsground in Newcastle, at the Bus Depot and at Gregson Park in Hamilton, and at the North Lambton Depot of the Hunter Water Board. The Obelisk and North Lambton sites are rock sites. Approximate alluvial depths (in metres) are indicated in Figure 2 for the other sites.

Sampling at a rate of 125 samples per second, simultaneous 33-second long measurements of ground velocity were recorded at all six sites with programmed triggers at 3:30, $3: 35$, and 3:40 a.m.on July 27,28 , and 29,1991 . On July 29 the seismographs were redeployed in a north-south array (Figure 2) that included a rock site in Merewether and alluvial sites at Mitchell Park, the Sportsground, and Carrington Park. The seismographs at these sites and at North Lambton Depot were triggered at 3:30, 3:35, and 3:40 a.m. on July 30 and 31, and on August 1 . The arrays were as near as possible, coincident with geologic sections prepared by Coffey \& Partners (1991) from their compilation of soil borings. Alluvial recording sites were chosen as close as practicable to boring sites, within constraints imposed by the need for secure housing (in small sheds with cement floors). The Sportsground recordings were made adjacent to a site where downhole shear velocities were obtained from a seismic cone penetrometer test by D.J. Douglas \& Partners (1991).
The second experiment consisted of day-time recordings at alluvial sites on July 30 and 31, and on August 1. For these recordings there was no reference rock site; the aim was to sample a large number of sites, including array sites, with the idea of identifying "site periods". Day-time recordings at array sites provided the opportunity to compare microtremors with different amplitude levels, and to examine possible differences between day-time and night-time signatures that might be due to microtremor source effects. As discussed below, while spectral amplitudes during day-time were found to be an order of magnitude greater than at night, no discernible differences were evident in spectral shape for frequencies above $1 \mathrm{~Hz}$. Diurnal variation in microtremor excitation does not seem to affect the site resonance results obtained in this investigation. Likewise, meaningful site response information at high frequencies was obtained from day-time recordings in New York City (Field \& others, 1990).

\section{RELATIVE SITE RESPONSE}

Fourier transforms were calculated for 16 -second record lengths. The results are given in terms of spectral modulus (square root of the power spectrum), for wave frequencies up to $15 \mathrm{~Hz}$. The velocity spectrum of the bedrock ground motion produced by the December 28 earthquake was probably in the middle of this frequency band (McCue et al., 1990). Comparison of rock sites spectral ratios of simultaneous recordings at North Lambton Depot and Merewether (both permanent recording sites) are shown in Figure 3. Ratios are shown for several triggers to display their variability. The absence of pronounced minima and maxima in the spectral ratios indicates that their seismic response is very similar. North Lambton is much further $(8$ $\mathrm{km}$ ) from the ocean than Merewether and the Obelisk, which are within a few hundred metres of the shore.

While it does not appear that the predominant microtremor source at high frequencies is oceanic, it was decided to use the coastal rock sites as reference sites so as to eliminate any possibility that the alluvial amplification effects discussed below are exaggerated by effects of differing distances from the ocean.

\section{Comparison of Alluvial and Rock Sites}

In the site response comparisons, results are shown for both horizontal components, north-south and east-west. In each case, spectral ratios for up to nine microtremor records are shown in order to display their variability. At the No. 1 Sportsground site, the thickness of alluvium and surficial fill is $31 \mathrm{~m}$. Figure 4 shows a pronounced microtremor amplification, relative to rock, (Obelisk site) at wave frequencies near $1.7 \mathrm{~Hz}$ (wave period $0.6 \mathrm{sec}$ ).

Amplification in this frequency band would also have occurred during the Newcastle earthquake, but presumably not to the same extent (factor of 18) as shown here for the microtremors. The amplification at this site occurs at a frequency considerably lower than the predominant frequency of the incoming earthquake motion, i.e. the amplification effect here is not strongly tuned with the earthquake spectrum. The effect of this amplification would have been greatest for larger, lower frequency structures such as the grandstands, which were damaged beyond repair. A second set of spectral ratios between the Sportsground and rock was 

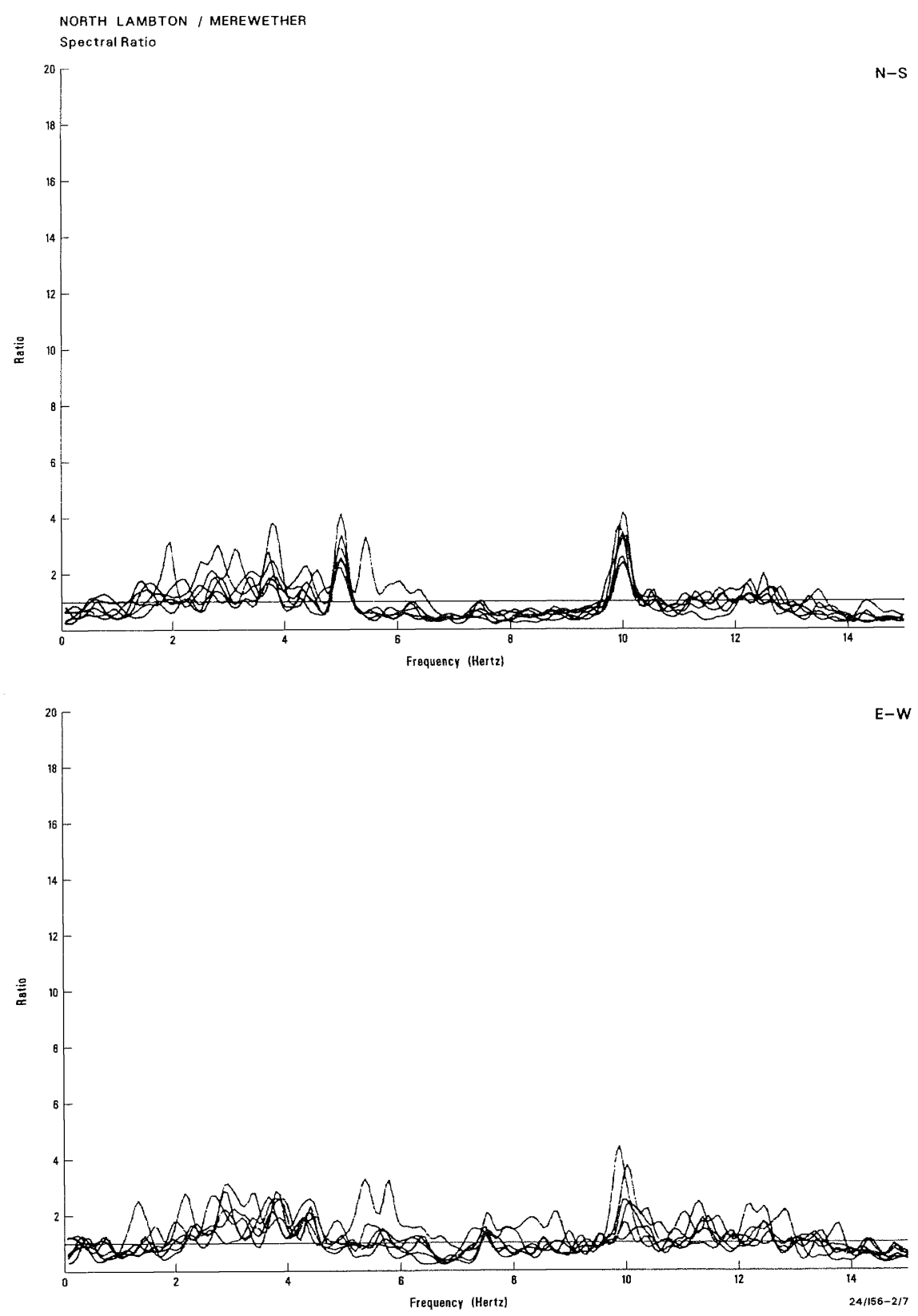

Figure 3 Spectral ratios of microtremors recorded at the two rock sites at Merewether and North Lambton. Note the absence of spectral peaks compared with those of figures 4 to 9 for the alluvial site ratios.

obtained from simultaneous recordings at Merewether. The ratios exhibit a pronounced maximum at $1.6 \mathrm{~Hz}$, with amplitudes about 50\% higher than the Sportsground/Obelisk ratios.

Similar results were obtained for the response at Carrington Park, where the thickness of fill and alluvium is approximately $40 \mathrm{~m}$ and there is a broad spectral maximum centred at $1.4 \mathrm{~Hz}$. Figure 5 shows results for Mitchell Park, where the alluvial thickness is believed to be less than $10 \mathrm{~m}$. Here the amplification occurs in a band around $3 \mathrm{~Hz}$ (period $0.3 \mathrm{sec}$ ), closer to the predominant frequency of the incoming earthquake motion than in the case of the deeper alluvial sites. The effect of the amplification in this case would have been greatest for structures tuned to this band, typically 2and 3-storey buildings.

Results for another shallow site, Gregson Park, are shown in Figure 6. Here the surficial material is landfill, which may explain why the amplification effect is more severe than at Mitchell Park. Maximum amplification occurs around $6 \mathrm{~Hz}$, which is probably close to the predominant frequency of the bedrock earthquake motion. At some sites, the microtremor amplification effect is not so readily interpretable in terms of a simple resonance. An example of more complex site response is the Bus Depot (Figure 7). Here the alluvial depth is $25 \mathrm{~m}$, and the resonance would be expected to occur at about $2 \mathrm{~Hz}$. While amplification at this frequency is 

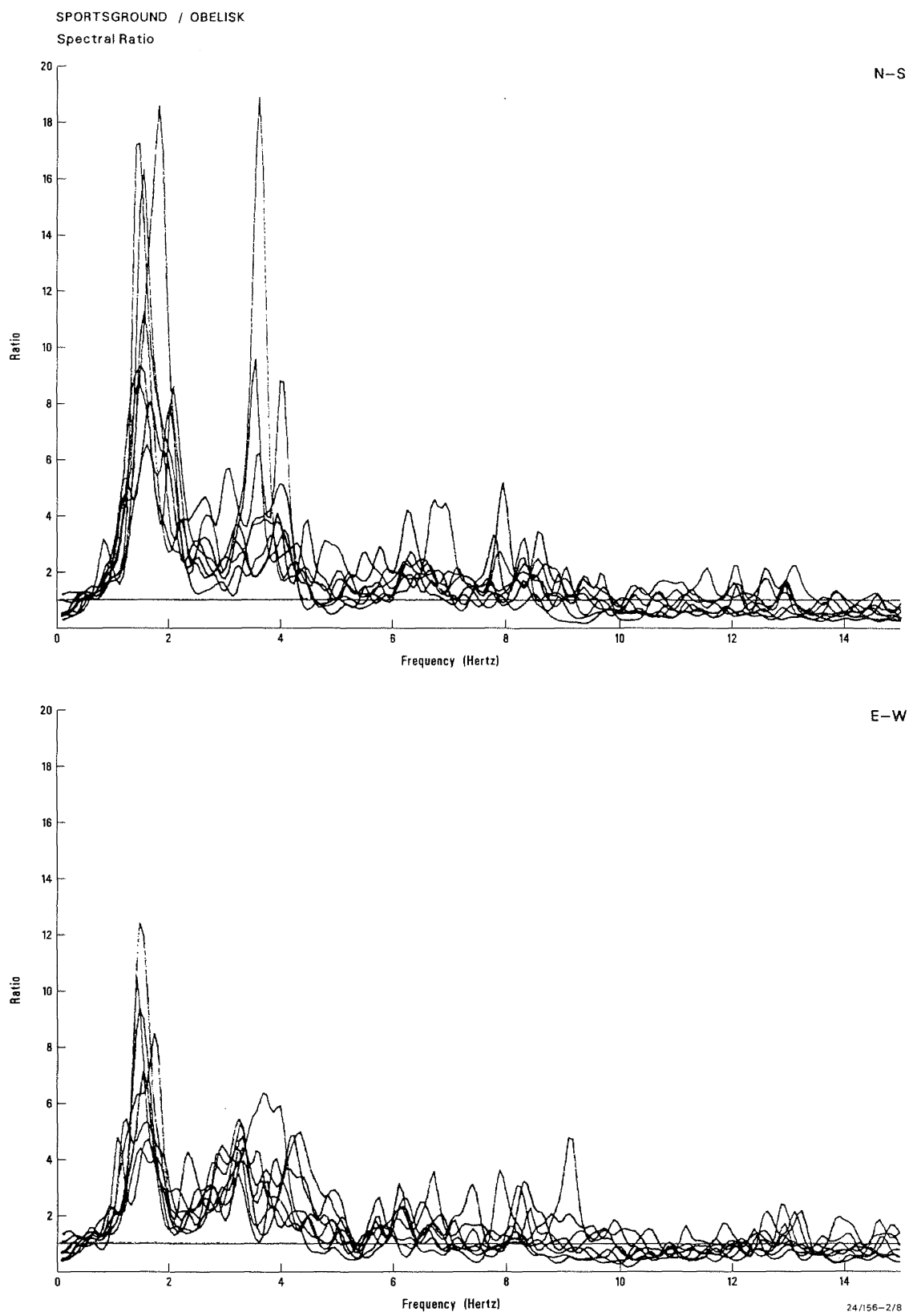

Figure $4 \quad$ Spectral ratio ( $N$-S and E-W components) of the Sportsground site (31 m alluvium) relative to the King Edward Park Obelisk site (rock). Eight independent obsenvations are plotted.

apparent for the north-south component, it is absent for the east-west component. In this area the alluvial thickness increases very rapidly to the east, from zero depth in the neighbourhood just south of Gregson Park (Figure 2). Shear waves polarized north-south would reflect vertically from the alluvium-bedrock interface, but east-west polarized waves would not. A sloping interface is a likely cause of the complicated spectral ratios in Figure 7. A simple site-resonance effect occurs in the restricted case of near-horizontal layering and sharp contrast in rigidity between alluvium and rock. A gradual increase in rigidity with depth, caused by the presence of residual soils or deeply weathered rock between alluvium and bedrock, can also complicate site response effects.

\section{COMPARISON OF DAY AND NIGHT RECORDINGS}

The night-time recordings were undertaken because of apprehension that day-time cultural noise might render results too unrepeatable to be useful. This apprehension proved in general to be misplaced in terms of the identification of "site periods". Figure 8 shows spectral ratios of day and night recordings (both horizontal components) at the Obelisk rock site. While there is a strong contrast in the strength of the microtremors, they are spectrally similar for frequencies above $1 \mathrm{~Hz}$. Figure 9 shows results for the alluvial Sportsground site. Note that the scale of this plot differs from the other spectral ratio plots. Here the day/night ratio is about 15 , more than twice that for the 

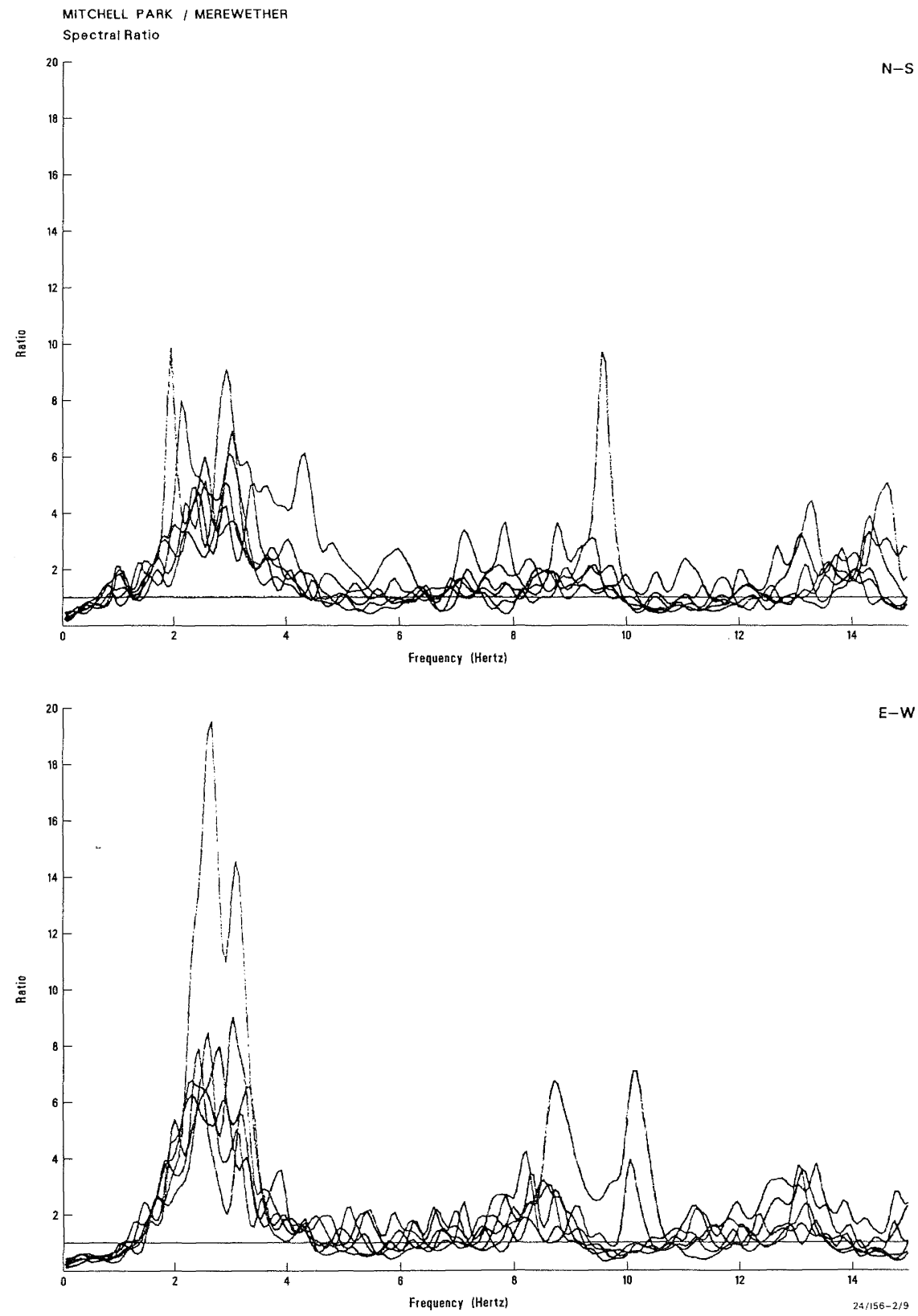

Figure 5 Spectral ratio of the Mitchell Park ( $8 \mathrm{~m}$ alluvium) relative to the Merewether site (rock).

Obelisk, and again there is no discernible spectral trend above about $1 \mathrm{~Hz}$. By inference, the alluvium/rock spectral ratios would show diurnal variation, and would be greater during day-time when microtremors are stronger. This would present yet another difficulty in interpreting the microtremor results in terms of degree of amplification. For lack of an adequate basis, no attempt is made herein to interpret the amplitudes.

\section{SITE RESONANCE FREQUENCYAND ALLUVIAL DEPTH}

The most significant result of the microtremor monitoring experiment is the documentation of site-dependent alluvial response effects. It is also significant that, for most alluvial sites, the amplification effect can be interpreted in terms of the simplest possible model, relating the resonance frequency to the depth and rigidity of the alluvial and/or fill layer. Figure 10 shows the data for all alluvial sites where a site resonance frequency is identifiable. The dashed lines show the frequency-depth relation that are calculated assuming all sites have a seismic shear-wave velocity of $200 \mathrm{~m} / \mathrm{sec}$ (upper curve) or $160 \mathrm{~m} / \mathrm{sec}$ (lower curve). The calculated frequency is the shear-wave velocity divided by four times the alluvial depth. The data exhibit the hyperbolic relation that is predicted by the simple quarter-wavelength resonance theory. The average shear-wave velocity deduced from Figure 10 is independent of, but compatible with geotechnical results at nine sites (IEAust, 1990; Poulos, 1991) where shear moduli have been estimated from standard penetration tests. The 

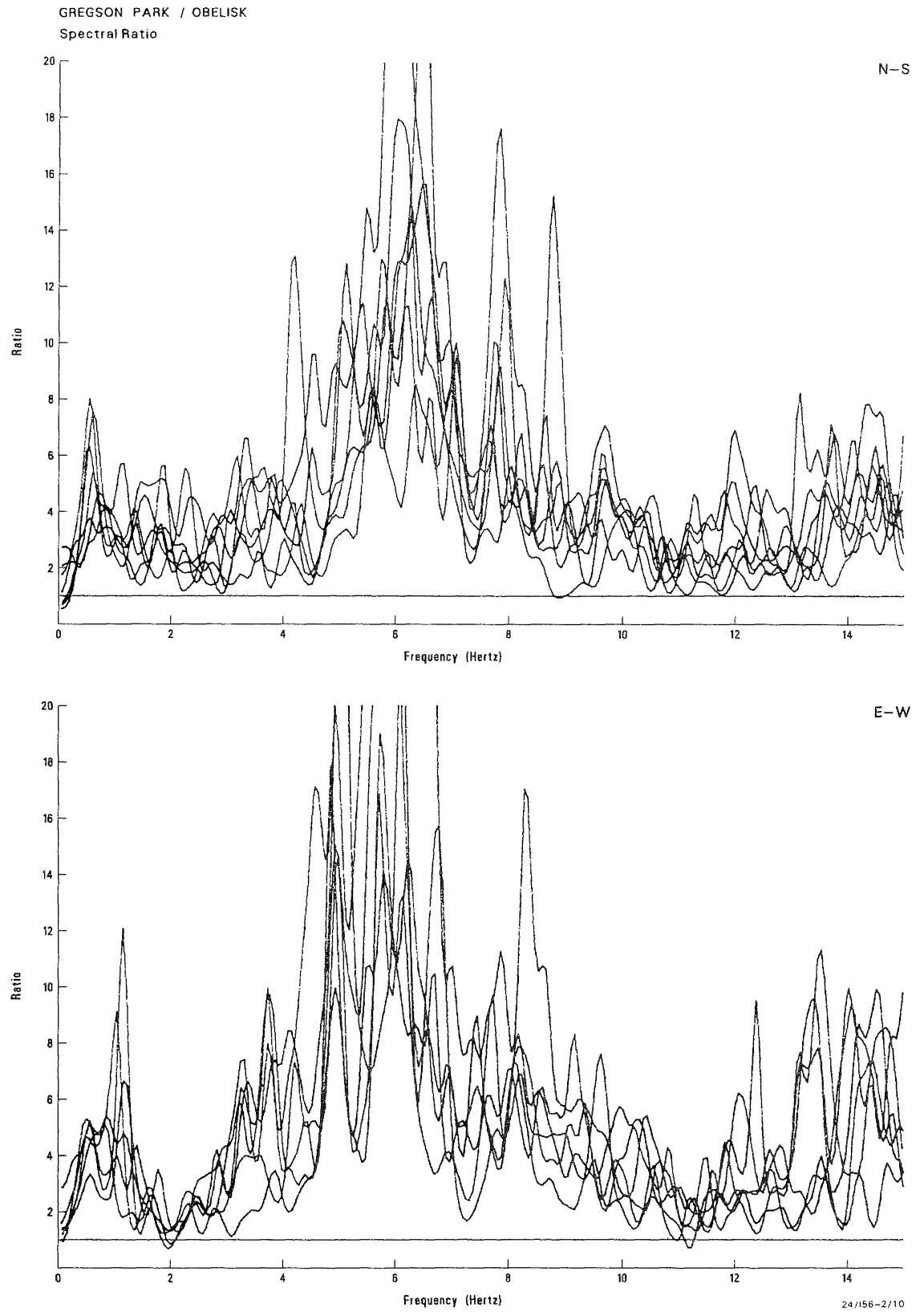

Figure 6 Spectral ratio of the Gregson Park (7 $m$ alluvium) relative to the King Edward Park Obelisk site (rock).

median shear velocity at the surface is $160 \mathrm{~m} / \mathrm{sec}$.

At a tenth site, the Sportsground, shear wave velocities were obtained to a depth of $20 \mathrm{~m}$ using the cone penetrometer method (D.J. Douglas \& Partners, 1991). The average velocity in this depth interval is $153 \mathrm{~m} / \mathrm{sec}$. The data for shallow depths in Figure 10 seem more compatible with the curve for $160 \mathrm{~m} / \mathrm{sec}$, while for greater depths there is a better fit to the curve for $200 \mathrm{~m} / \mathrm{sec}$. This increase in velocity with depth may not occur in all cases depending on stratigraphic variations. The scatter of the data in Figure 10 is attributable to variations in shear velocity and errors in depth estimates. The largest deviation is for Mitchell Park, which is plotted at $3 \mathrm{~Hz}$ and $8 \mathrm{~m}$. The alluvial depth estimated here by interpolation between nearby measurements, may be much too shallow.

\section{DISCUSSION}

Microtremor observations have shed light on the seismic response of sites underlain by alluvium and/or fill. At most sites, seismic amplification occurs at frequencies that are predictable in a simple way in terms of alluvial rigidity and thickness: where these quantities are unknown, the resonant frequency can be ascertained easily at most sites from microtremor monitoring. At sites where there is a steep interface between alluvium and bedrock, amplification effects 

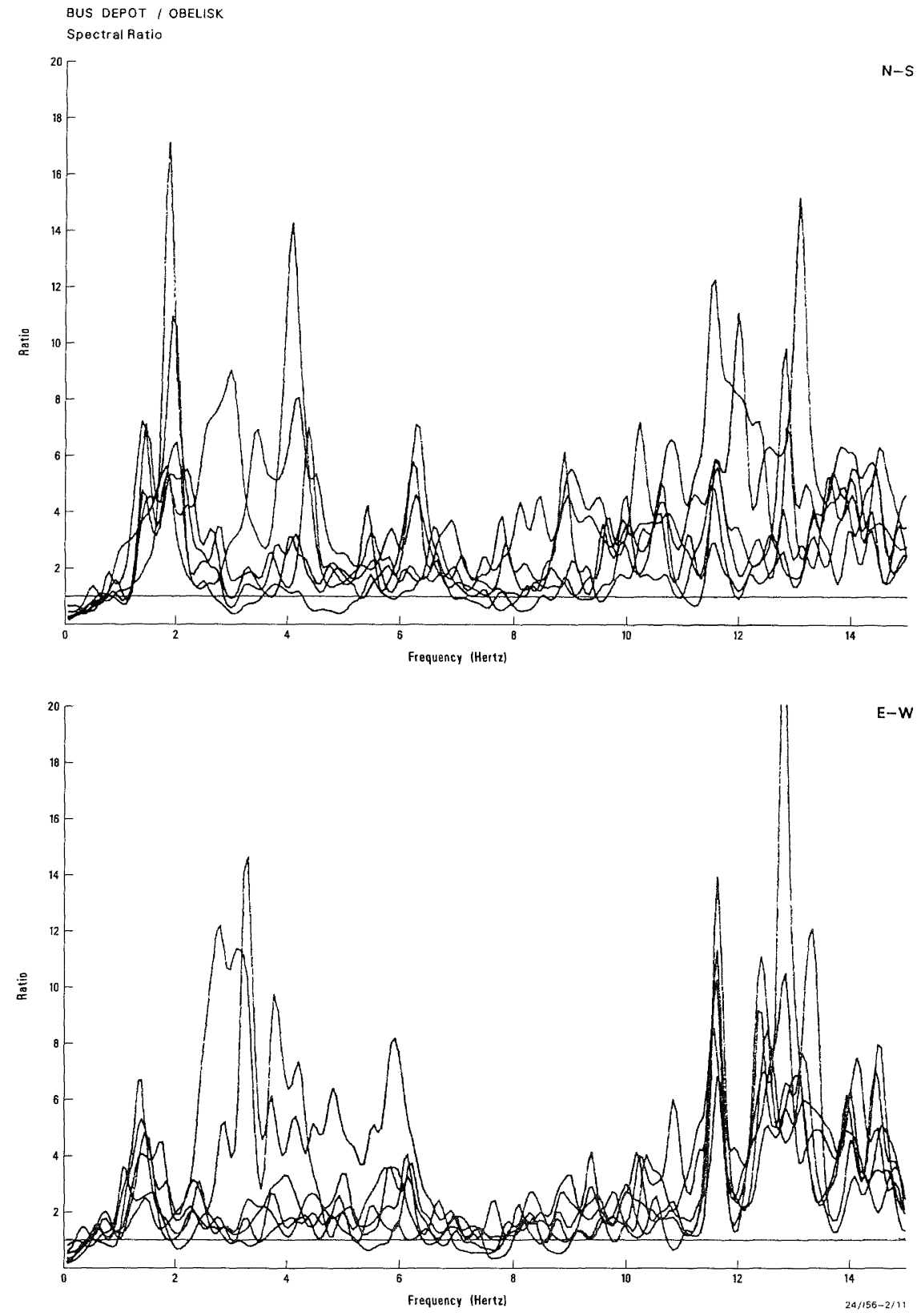

Figure $7 \quad$ Spectral ratio of the Bus Depot (25 $\mathrm{m}$ alluvium) relative to the King Edward Park Obelisk site (rock).

are complex and depend on the direction of approach of incoming seismic waves. Relative seismic response will then depend on the location of the earthquake.

Geographic variation in the severity of ground shaking in future earthquakes will not exactly replicate that experienced in 1989. However it is plain that surficial geology is a principal determinant of geographic variation in the strength and character (frequency content) of ground shaking. These observations reinforce the recommendation of the Institution of Engineers, Australia (1990) that "specific provision should be made for the amplification effects associated with alluvial soils and filled areas". This could be effected by using appropriate site-dependent loading coefficients for ordinary structures, and for large and/or critical structures by means of appropriate site investigations which could include microtremor monitoring as a means of determining site resonance frequencies. The best available estimate of the average degree of amplification at alluvial sites in Newcastle is the factor of $3 \pm 1$ obtained by IEAust (1990) on the basis of the apparent seismic intensity anomaly of 1.5 units. The microtremor results show that the amplification effect would have been manifest at different wave frequencies at different sites, thus affecting differing classes of structures. This effect is explicit in the calculations of Poulos (1991), who obtained amplification factors consistent with the estimate of IEAust (1990). 


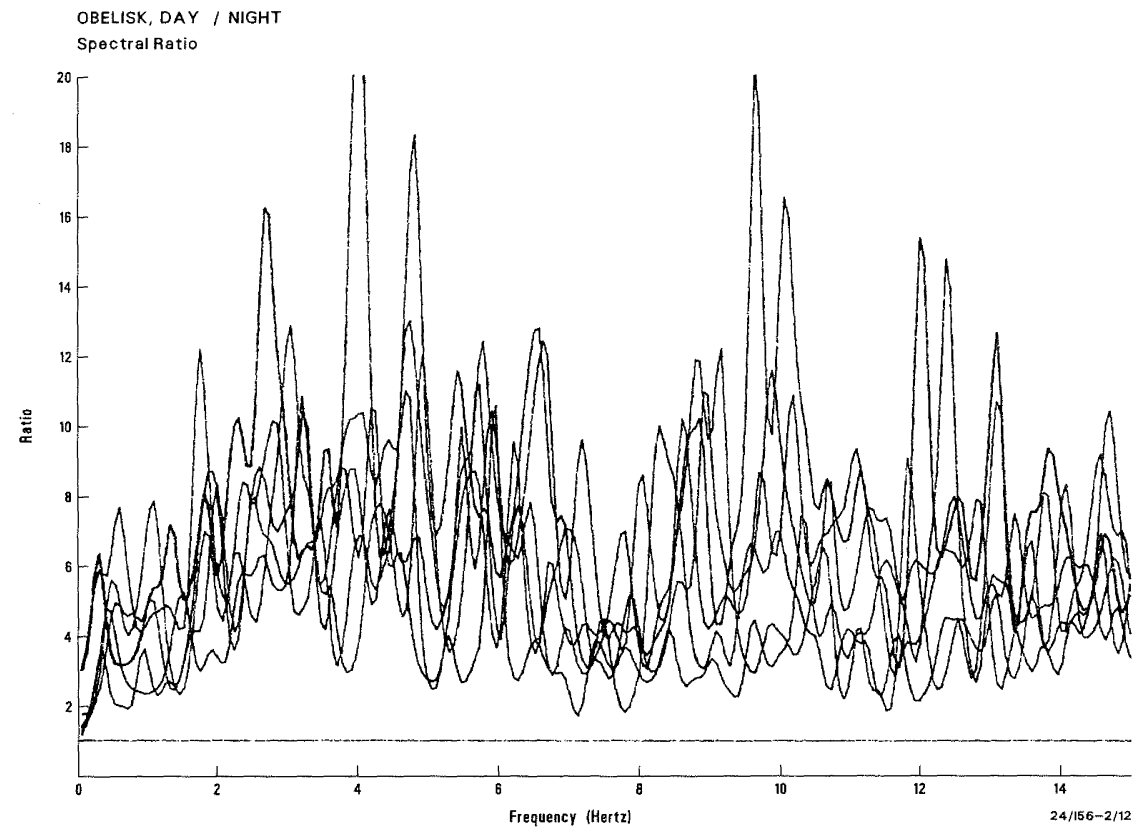

Figure 8 Day/night spectral ratio (both horizontal components plotted) at the King Edward Park Obelisk site (rock).

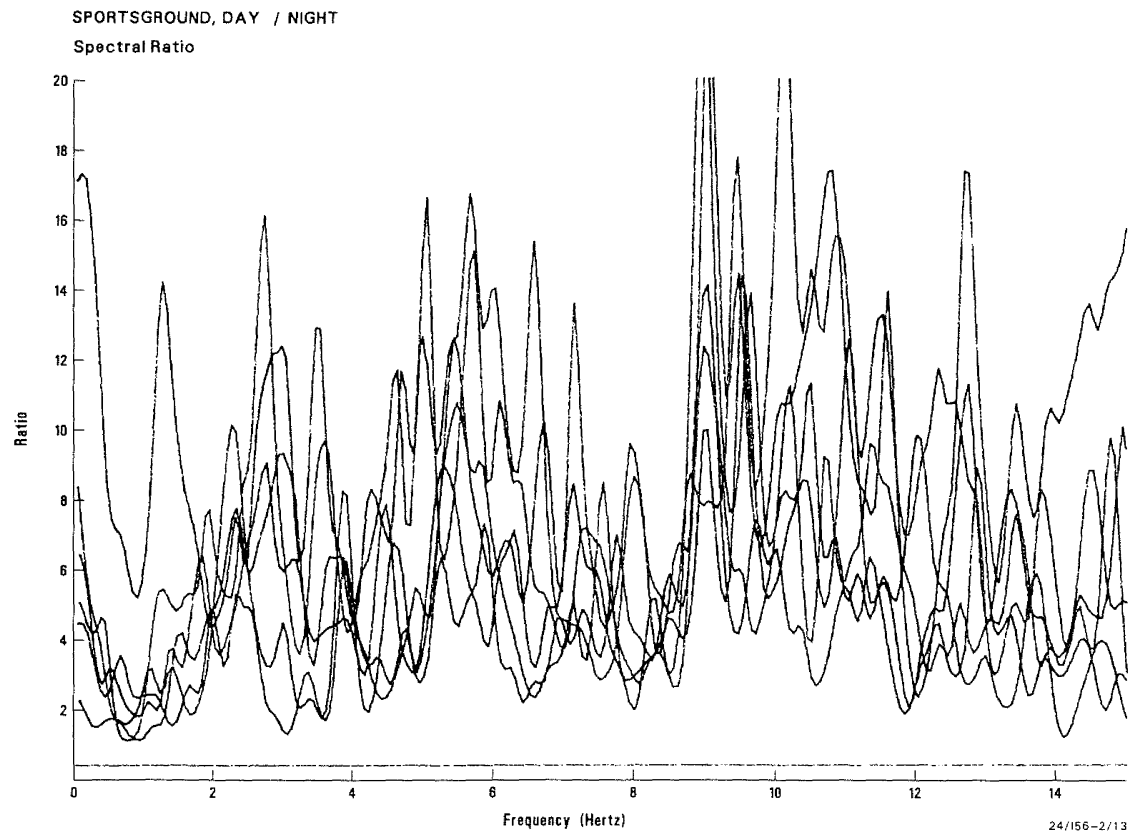

Figure 9 Day/night spectral ratio (both horizontal components plotted) at the Sportsground. 


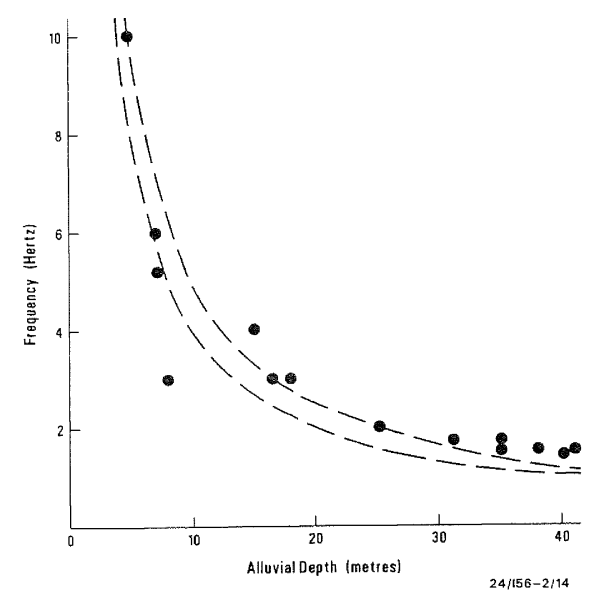

Figure 10 Relation between observed microtremor resonance frequency $(\mathrm{Hz})$ and depth of alluvium or fill. The dashed lines are quarter wavelength frequencies calculated by dividing the shear-wave velocity $(200 \mathrm{~m} / \mathrm{s}$ top line, $160 \mathrm{~m} / \mathrm{s}$ bottom line) by four times the alluvial thickness.

\section{ACKNOWLEDGEMENTS}

Douglas Chapman and David Pavey, Newcastle City Council Engineers, assisted with access to seismograph sites instrumented in this study. Arthur Love of Coffey Partners International, Newcastle, assisted in determining alluvial depths at instrument sites from local borehole data, and Steven Jones of D.J. Douglas \& Partners, Newcastle, provided the downhole cone penetrometer test results obtained at the No. 1 Sportsground. The participation of one of us (H.K.) was sponsored jointly by the Australian Academy of Science and the Japan Society for the Promotion of Science.

\section{REFERENCES}

Chandler, A.M., J.W. Pappin and A.W. Coburn (1991). Vulnerability and seismic risk assessment of buildings following the 1989 Newcastle, Australia, earthquake; Bulletin of the New Zealand National Society for Earthquake Engineering, Vol. 24, No. 2, pp. 116-138.

Coffey Partners International Pty Ltd (1990). Newcastle Earthquake Study - Geotechnical Aspects; in Institute of Engineers, Australia (1990), ed. R.E. Melchers.
D.J. Douglas \& Partners Pty Ltd (1991). Report to Newcastle City Council on cone penetrometer tests at the No. 1 Oval.

Field, E.H., S.E. Hough and K.H. Jacob (1990). Using microtremors to assess potential site response: a case study in Flushing Meadows, New York City; Bulletin of the Seismological Society of America, Vol. 80, No. 6, pp. 1456-1480.

Gaull, B.A., H. Kagami, H. Taniguchi, P.J. Gregson, G. Woad and B. Page (1991). The microzonation of Perth, Western Australia, using microtremor spectral ratios; Bureau of Mineral Resources, Mundaring.

Gibson, G., V. Wesson and K. McCue (1990). The Newcastle earthquake aftershock and its implications; in Proceedings, Conference on the Newcastle Earthquake, The Institution of Engineers, Australia National Conference Publication No. 90/15.

Herbert, C. and R. Melby (1980). A guide to the Sydney Basin; Geological Survey of New South Wales, Bulletin 26.

Institution of Engineers, Australia (1990). Newcastle Earthquake Study, ed. R.E. Melchers, 155 p.

Kagami, H., S. Okada, K. Shiono, M. Oner, M. Dravinski, and A.K. Mal (1986). Observation of 1- to 5-second microtremors and their application to earthquake engineering. Part III. A two-dimensional study of site effects in the San Fernando Valley; Bulletin of the Seismological Society of America, Vol. 76, No. 6, pp. 1801-1812.

McCue, K., V. Wesson and G. Gibson (1990). The Newcastle, New South Wales, earthquake of 28 December 1989; BMR Journal of Australian Geology \& Geophysics, Vol.11, pp. 559-567.

Poulos, H.G. (1991). Relationship between local soil conditions and structural damage in the 1989 Newcastle earthquake; Civil Engineering Transactions, Institution of Engineers, Australia, Vol. CE33, No. 3, pp. 181-188.

Rynn, J.M.W. (1991). The 1989 Newcastle Earthquake: the Source, the Size, the Observations - Lessons for Australia, in Proceedings, "What we have learnt from the Newcastle Earthquake", 24-25 October 1991 Conference, Newcastle, ed. J.M.W. Rynn. 